\title{
Quality Assessment of a Dental Centre Using EFQM Excellence Model: A Case Study on King Fahd Armed Forces Hospital
}

\author{
Ala'Eddin Mohammad Khalaf Ahmad \\ Assistant Professor of Marketing, Faculty of Economics and Administration \\ King Abdulaziz University, Jeddah, Kingdom of Saudi Arabia \\ Tel: 966-56-852-7444Ｅ-mail: amahmed1@kau.edu.sa; aladdin.a.h@hotmail.com
}

Yasser Abdullah Rhbeini

Director of Dental Centre in King Fahd Armed Forces Hospital, Jeddah, Kingdom of Saudi Arabia

Omar Zayyan Alsharqi

Assistant Professor of Public Health Management, Faculty of Economics and Administration

King Abdulaziz University, Jeddah, Kingdom of Saudi Arabia

Najla Kadi

Lecturer in Health Services and Hospital Management Faculty of Economics and Administration

King Abdulaziz University, Jeddah, Kingdom of Saudi Arabia

Received: November 9, 2012

Accepted: November 27, 2012

Online Published: November 27, 2012

doi:10.5430/bmr.v1n4p121

URL: http://dx.doi.org/10.5430/bmr.v1n4p121

\begin{abstract}
This research aimed to investigates the quality assessment of a dental centre using EFQM excellence model a case study on King Fahd Armed Forces Hospital (KFAFH). The literature review reveals that there is an extensive body of research that addresses EFQM model in general but there is less emphasis on the hospital and dental centres in particular. In order to explore this issue, a quantitative method was used to collect primary data through a questionnaire, which was administered in the dental centre at KFAFH in Jeddah- Saudi Arabia. A purposive sampling was used to choose the participants in this research. In total, 50 respondents (managers, faculties, and students) participated in this study. The results confirm significant positive in the influence of EFQM factors on each other's. Furthermore, the results exhibit that hospital management might benefit more by placing more emphasis on an integrated EFQM model and recognising the EFQM influences on their dental centre. This research contributes to the academic and practical knowledge as being one of the first attempts to investigate empirically the EFQM dental centre at Arab Region. This research integrates, refines and extends the empirical work conducted in the field of health services in Gulf Countries. It raises many implications for managers in this hospital, such as considering the importance of EFQM and the vital role this model plays in the performance of Saudi hospitals. This research provides useful guidelines for further and future research possibilities such as exploring the influence of the EFQM model in the whole hospitals in Saudi Arabia.
\end{abstract}

Keywords: EFQM, Quality assessment, Dental centre, KSA

\section{Introduction}

According to Camison (1996), Quality evaluation and appraisal are the latest health services institution buzz word. It is shaped at present as a fundamental strategy for the support and improvement of the competitiveness. The European Foundation for Quality Management (EFQM) excellence model is a non-prescriptive framework and the most comprehensive and prevailing quality models which are applied in many countries and sectors. The European Foundation for Quality Management (EFQM) was founded in 1988 with the endorsement of European commission. EFQM model is a membership based, not for profit organization (Moller and Sonntag, 2001). The EFQM excellence model (a multidimensional quality model) was developed by the founding members and introduced the principle of 
self-assessment and the European Quality Award Program. According to the foundation, the aim of EFOM excellence model is to represent the total quality management (TQM) philosophy that can be applied to all organization irrespective of location, size or sector (George et al, 2003). EFQM excellence model is a comprehensive pattern for total quality management and presents a strategic option and an integrated management philosophy for organizations. Calvo-Mora (2006) aims that this excellence model allows organizations to reach their objectives effectively and efficiently and to achieve sustainable competitive advantage. According to Tari (2006) EFQM excellence model is an offer to improve the activities and performance continuously by establishing TQM philosophy in both private and public sector. EFQM excellence model is playing a vital role in organizations' structure, management, self assessment tool, frame work for comparison with other organizations and consequently an effective tool to identify areas for improvement (Jackson and Bircher, 2002).

Dental education has been considered as one of the continuous development throughout the world (Gaengler and Falk-Nilsson, 2002). The Kingdom of Saudi Arabia (KSA) established 19 dental institutes recognized by the constitutional regulatory and registration authority (Deans Council of Dental College, Saudi Arabia, 2011). The outcomes of undergraduate dental institute reproduction have naturally started an internal debate regarding the end health service quality. The evaluation on dental institutes can be on their infrastructure, medical equipments, financial capabilities, teaching faculty, student selection criteria, materials, and clinical quality (Bokhari, 2006).

A research study is proposed that will assess a teaching dental center's quality around its core activities using the nine EFQM Model excellence concepts at three different participation levels in KFAFH.

The research outcome will provide worthy insights for dental practitioners into the non-clinical aspects in providing quality in dental services that are most valued by patient receiving treatment with their practices.

\section{Literature Review}

The core purpose of EFQM model is to assess excellence levels attained in organizations, guide to continuous improvement. Looking to the term "excellence" is used because the model focuses on what an organization does, or could do to provide an excellent service or product for its customers, service users or stakeholders (Rosa and Amaral, 2007). There are different ways in using EFQM Excellence Model: a self-assessment tool; benchmarking with other organizations; and a structure for the organization's management system (Saraiva et al, 2003), but it has come to be widely used as a self-assessment tool in health services organizations. The nine principles of EFQM (Vallejo et al, 2007; Rosa and Amaral, 2007) as the following:

1) Leadership: The achievement of the mission and vision needs excellent leaders who have the ability to develop and facilitate. They develop organizational values and systems required for sustainable success and implement these via their actions and behaviors.

2) Policy and strategy: The implement of excellent organizations mission and vision will be by developing a stakeholder focused strategy that takes account of the market and sector in which it operates. Policies, plans, objectives and processes are developed and deployed to deliver strategy.

3) People: Excellent organizations should focus on how to manage, develop and release the full potential of their people at an individual, team-based and organizational level. They promote fairness and equality and involve and empower their people.

4) Partnerships and resources: The plan of excellent organizations should focus on how to manage external partnerships, suppliers and internal resources in order to support policy and strategy and the effective operation of processes.

5) Processes: Excellent organizations should concern on designing, managing and improving processes in order to fully satisfy, and generate increasing value for, customers and other stakeholders.

6) Customer results: Excellent organizations should thorough measure and achieve outstanding results with respect to their customers.

7) People results: Excellent organizations should thorough measure and achieve outstanding results with respect to their people.

8) Society results: Excellent organizations should thorough measure and achieve outstanding results with respect to society.

9) Key performance results: Excellent organizations should thorough measure and achieve outstanding results with respect to the key element of their policy and strategy. 
The current research will cover the self-assessment technique. Self assessment depend on a regular comparison of activities and results of an organization with the excellence model (Hillman, 1994) and it takes part in identifying strong points or improving areas that consequently could help to establish advance plans that should be integrated in the organizational strategic plans (Ritchie and Dale, 2000).

The EFQM Excellence Model is a non-prescriptive framework depends on nine criteria (Figure 1). Five of these are "Enablers" and four are "Results". The "Enablers" criteria cover what an organization does. The "Results" criteria cover what an organization achieves. "Results" are caused by "Enablers" (Gorji and Emaami, 2012).

The model is realizing that there are many approaches to achieve sustainable excellence in all aspects of performance and it based on the premise that excellent results with respect to performance, customers, people and society are achieved through partnerships, resources and processes. The arrows emphasize the dynamic nature of the model. They show innovation and learning to improve enablers that in turn lead to improve results (Gorji and Emaami, 2012). In the following sections, each criterion of the nine EFQM model will be discuss:

\subsection{Leadership}

Special technical skills and management capacities must be owned by leaders. They must be conscious of the importance of their position. Leaders' actions are essential for the sustainable achievement of organizational goals. Stakeholders' expectations must be considered (Martin, 2004). In other words, leaders should consider the ethical dimension of their position. They should be responsible for the impact of organizational activities on stakeholders.

Leaders have a notable role as enablers. They must be involved with the satisfaction of each group of stakeholders. The reaching of the organizational main goal needs the ability of communication and convincing as they are a part of leadership resources. In this sense, leaders must know how to motivate the organizational members and other key agents (Vallaster and Chernatony, 2006; Martín-Castilla and Rodríguez-Ruiz, 2008).

Leader has an important role to do as an agent of change for continuous improvement. Leaders have an idealistic character knowing where to lead the organization. To reach organizational goals, they should define the organizational mission both in the market and in the social context, facilitate means and consider organizational culture as it is one of the biggest barriers to create and to transfer knowledge (De Long and Fahey, 2000).

H1. There is a positive relationship between leadership and policy and strategy.

H2. There is a positive relationship between leadership and people.

H3. There is a positive relationship between leadership and partnership and resources.

\subsection{Policy and strategy}

Excellent organizations' policy and strategy must be based on the knowledge of key agents' expectations and needs. The different interests of stakeholders must be balanced. Thus, the information gathered from stakeholders with other additional sources of information and with performance indicators should be consummated. The overall sum of this data (internal and external sources) is then incorporated into the policy and strategy formulation process. Grant (1995) indicates that the strategy is in charge of creation and maintenance of the competitive advantage.

The organization must concern about the most of learning, innovation and creativity. Those aspects are fundamental for the development of the structural capital (organizational and technological). Structural capital plays an integral role in knowledge creation and management (Empson, 2001; Suddaby and Royston, 2001).

Organizations have to set their vision and values for achieving their objectives. They must stratify the policy and strategy dimension with the mission-vision-values dimension. People and resources have to be applied to this task. Obviously, organizational capital is extremely important here. Elements such as culture, structure, business processes, etc., related with an excellence leadership, are essential. This visionary leadership is a human capital element (Suddaby and Royston, 2001; Martín-Castilla and Rodríguez-Ruiz, 2008).

Organizations will convey their vision, values and strategic objectives involving all the people in their project. The disclosing of communication requires human capital and a set of capacities aligned with strategy. Structural capital will submit processes for communication and strategy implementation (Empson, 2001; Suddaby and Royston, 2001).

$\mathrm{H} 4$. There is a positive relationship between policy and strategy and processes.

H7. There is a positive relationship between policy and strategy and people.

H8. There is a positive relationship between policy and strategy and partnership and resources. 


\subsection{People}

The organization that search for excellence must be concerned with the welfare of people. Ethical values are strictly necessary in human capital management's. Individual and professional development must be united. That also means a labor climate based on transparency, integrity, mutual confidence and participation. The identification with the organization has to be strengthened by sharing its mission, vision, values and strategy (Martín-Castilla and Rodríguez-Ruiz, 2008).

The commitment of organizations has to design a framework of professional careers and wages in which justice, impartiality and equality are superior values.

The challenge confront by the organization is how to manage the seeming paradox of balancing individual creativity and productivity (Chang and Birkett, 2004). The communication is a major issue in the relations between people and organizations.

Recognition, attention and support mechanisms in sub standard are linked with human capital (values, attitudes, capacities and leadership), and organizational capital (culture, structure, organizational learning and processes).

Generally, organizations that seek excellence focus on augmenting their specific human resource advantages. The attraction and retention of highly skilled and motivated employees will increase company competitive in international markets (Chadee and Kumar, 2001). Thus, the clear stimuli for motivation are professional development, satisfaction, leadership, reputation and balance between family and work.

H5. There is a positive relationship between people and processes.

\subsection{Resources and Alliances}

Excellent organizations are attached through alliances with agents that optimize the value chain. Collaboration and cooperation relations will be based on confidence, honesty and transparency. Suppliers and other allies will be involved in the different management systems (Martín-Castilla and Rodríguez-Ruiz, 2008).

It must be said that the excellent organization will develop procedures for controlling the expenditure defined in the annual budget and its subsequent risks with regarding to economic and financial resources. Elements such as processes (structural capital) and leadership (human capital) are extremely important here (Martín-Castilla and Rodríguez-Ruiz, 2008).

Furthermore, the management of buildings, equipment and materials must follow environmental protection criteria. The consuming of resources must be rationalized. Significantly, recycling is especially advisable to reduce environmental effects. The element "processes" included in organizational capital is applicable here (Martín-Castilla and Rodríguez-Ruiz, 2008).

H6. There is a positive relationship between partnership and resources and processes.

\subsection{Processes}

In processes, the satisfaction of internal and external customer needs and expectations must be focused. Processes, aligned with strategy, mission and objectives, have to add value to customers and other stakeholders (Martín-Castilla and Rodríguez-Ruiz, 2008).

The structural capital measures are those that help to identify the elements of organizational processes and activities and link them to the creation of company value (Carroll and Tansey, 2000). On the other hand, relational capital includes all knowledge assets accumulated by the organization from its relationships with other key agents that interact in the organizational environment (Bontis, 2001).

H10. There is a positive relationship between processes and people results.

H11. There is a positive relationship between processes and society results.

H9. There is a positive relationship between processes and customer results.

\subsection{Customer results}

Results concerning customers can be measured using indicators or assessing their percept in the EFQM model. Different aspects must be considered (Martín-Castilla and Rodríguez-Ruiz, 2008)

- Products and services according to customer perception. The degree of satisfaction and idealization should be measured.

- Products and services reliability (quality warranty). Level of transparency and honesty. 
- The social impact perception (derived from organisational activity).

- Organisational reputation.

- Optimisation Level of owners' and investors' goods compatible with the mission, vision, and values integrated in the system of ethics management.

- Interests balance. Impartiality in profit distribution.

- $\quad$ Fluent communication with shareholders and stakeholders. Information has to be transparent and truthful.

H12. There is a positive relationship between customer results and key performance results.

\subsection{People results}

Adequately, this criterion fits with human capital elements (results concerning values, attitudes, aptitudes and capacities). In this research results will be measured using indicators or by assessing perception. Different aspects will be evaluated (Martín-Castilla and Rodríguez-Ruiz, 2008):

- The motivation of people with regard to the development of professional careers, communication, delegation, responsibility assumption, equal opportunities, involvement, leadership, learning opportunities, recognition, definition of objectives, performance evaluation, values, mission, politics and strategy, training, and promotion in the organisation;

- The satisfaction of people with regard to management, employment conditions, installation and services, health and safety conditions, salary, wages and benefits, relation between peers, change management, policy and environmental impact, organisational role in the community, and work environment;

- $\quad$ people's motivation and involvement with team work, training and development of professional careers; and

- $\quad$ People's satisfaction measurement, i.e. absenteeism index, accident index, complaints, people turnover, labour disputes, use of health, social and cultural benefits, and use of the organisation's installations (nursery school, etc.).

H13. There is a positive relationship between people results and key performance results.

H14. There is a positive relationship between people results and customer result

\subsection{Results in society}

Results in society are a key criterion that should not be neglect. A truly dynamic view of the enterprise must expand far beyond traditional boundaries to include business models that allow for corporate social responsibility, along with such matters as human competence, internal structure and stakeholder relationships and added value in general (Alle, 2000; Martín-Castilla and Rodríguez-Ruiz, 2008).

Organizations play an eminent role in the sustainability of the market, which is overall a social institution. This is the foundation of the corporate social responsibility approach.

It is possible to point to some areas (Allee, 2000; Martín-Castilla and Rodríguez-Ruiz, 2008):

- Organization's active participation in social activities: ethical behavior and spread of values in society; disseminating relevant information for the community; development of a policy of equal opportunities; wealth creation and its impact on the local and national economy; relations with relevant authorities - observation of the rules; openness and understanding with different social agents; and impact of the organization's publicity on social values.

- Organization's participation with the community: involvement in social and economic development - social cohesion through collaboration with public administration and third sector organizations; involvement in education and training of community members; support for cultural and social activities; and voluntary work and philanthropy.

- Organizational activities directed towards the removal of the damage derived from its activities and the life-cycle of products and services.

- Organizational information activities directed to preserve resources (resource sustainability). Activities for promoting good practice both in the organization and in society must also be considered.

- Organization's spreading of evaluations results in several areas (environment, ethics, risk at work, quality, etc.).

- Organization's social involvement and corporate reputation. 
H15. There is a positive relationship between society results and customer results.

H16. There is a positive relationship between society results and key performance results.

\subsection{Key results}

The key results in the EFQM consider the following aspects (European Foundation for Quality Management, 2005):

1) The maximize investors' value with sustainability in financial and economical results.

2) The improvement of the organisation's position and reputation in non-economic results.

3) Optimal and sustainable management of the following elements (the management should be aligned with mission, vision, values and strategic objectives) (Martín-Castilla and Rodríguez-Ruiz, 2008): processes; external resources including alliances; economy and finance; material goods; technology; and information and knowledge.

\section{Research Contribution}

This research seeks to make an original contribution to knowledge by investigating the EFQM excellence model in the health care industry in Saudi Arabia. This research contributes to the health services quality management discipline in finding out the role of quality management measured by European Foundation in delivering a better dental health service within the hospital industry. It investigates the latter so as to demonstrate the uniqueness of health service organisation and the importance of the dental services. EFQM factors namely, leadership, policy and strategy, people, partnership and resources, process, customer results, people results, society results, key performance results are the focus of this study as they all have an influence on each other and the outcomes of centre services. As such, this study attempts to contribute to the quality management knowledge and health services in particular.

This research has dealt with a neglected area in KSA, which is the quality management of health services. It is considered as new research in the diffusion of quality in the area of health services to gain an understanding of the relevance, effect and contribution of quality management to the Saudi Armed Forces Hospitals.

Such contribution will be beneficial both academically and professionally. Academically, this work aims to focus academic attention upon a neglected domain in the context of this research. And, professionally, managers will also look at the practical implications of such effort and the possibility of implementing the implication of this research in their actual relationships with their stakeholders (Ahmad, 2012).

\section{Aim and Objectives of the Research}

The broad aim of this research is:

To assess a dental center's quality around its core activities using the nine EFQM model excellence concepts at three different participation levels in King Fahd Armed Forces Hospital-dental center.

To achieve this aim, three objectives have been identified, which guided the investigation of the research.

1) To reveal the factors which constitutes the EFQM in dental center at KFAFH?

2) To examine the manager's, faculties, student's opinions regarding to the EFQM factors.

3) To identify the strengths, gaps and areas that needs improvement in this concept.

\section{Research Methodology}

\subsection{Research Design}

This research is a descriptive analytical research of the actual relationships that may exist between dependent and independent variables as stated in the research hypotheses. The research design constructed here is based on the hypotheses formulated. These hypotheses were formulated inductively from the researcher's observation and from the literature. The descriptive part is needed to describe and identify the research factors, which constitute the EFQM for dental centre at KFAFH.

In the analytical part, the research model is being tested through examining the relationship between the EFQM between each other factors in KFAFH in order to explore how far hospital managers, faculties, and students perceive these factors when making their decisions.

\subsection{Type of Research}

As this research aims to assess a dental hospital's quality around its core activities using the nine EFQM model excellence concepts at three different participation levels in KFAFH-dental centre. This research is used a single-sectional research survey in which just only one dental teaching centre operating in Jeddah health market 
included. It is a single cross-sectional design in which the collection of information from the research population and respondents performed once only (Sekaran, 2000).

\subsection{The Research Population}

\subsubsection{The Research Population}

Any research population must be accurately specified in order to collect the required data for the research problem (Sekaran, 2000). The research population consists of the military hospitals in the city of Jeddah/Saudi Arabia. The population in this research is defined as all the management, faculties, and students at the dental centre in KFAFH.

\subsubsection{The Research Respondents}

The rationale for selecting the respondents is that they have a sound knowledge and greater responsibility for managing relations with the quality than the lower level managers in the dental centre. In the same line, selecting the respondents from other levels (faculties and students) because they have also a good knowledge of different view regarding the quality in dental centre.

A total of 50 research questionnaire was distributed for all levels managements, faculties, and students covering all the EFQM model's key quality aspects.

The research was included top management (medical and administrative), faculties and students in KFAFH as displayed in table 1 below:

As mentioned previously this research was conducted in the dental centre of KFAFH, Jeddah. This centre contains 180 employees (60 dentists, 100 nurses, 20 Clarks). Five from the dentists work as a manger and 10 work as a faculty lecturers. There is 3 employee works as administrator. The dental centre consider as one of the training centre for graduate and postgraduate dental students. The numbers of the trainee almost are 35 students per year.

The research sample was cover 5dentist managers, 3 administrators, 10 faculties and 32 students.

\section{Data Analysis}

The objective of this section is to provide analysis of the hypotheses testing concerning the EFQM factors using simple regression techniques. Simple regression analysis, included as part of the Statistical Package for Social Science (SPSS) version 12.0, was conducted in order to test the research hypotheses.

\subsection{The Correlation Matrix}

Field (2000) explains that the correlation matrix is extremely useful for obtaining a rough idea of the relationships between predictors and the outcome, and for a preliminary search for multicollinearity in the data.

Table 2 shows the correlation matrix, which presents the value of the Pearson correlation coefficient between every pair of variables (2), the 1-tailed significance of each correlation and the number of cases contribution (2) to each correlation $(\mathrm{N}=50)$.

With regard to the relationships among predictors and the outcome, 36 out of the 36 EFQM factors had a significant positive correlation with each others. Between these variables all ranged from 0.277 to 0.888 with the correlation of all the 36 EFQM factors being significant, $\mathrm{p}<0.05$ and $\mathrm{p}<0.01$.

As such, this result supports the proposition that all of the 36 "EFQM" capabilities have significant positive relationship, in that each has a significant correlation with factors.

\subsection{EFQM}

Nine dimensions were suggested to EFQM including (leadership, policy and strategy, people, partnership and resources, process, customer results, people results, society results, key performance results). It additionally proposed that these factors have an influence on each other as discuss below.

6.2.1 Policy and strategy $=\mathrm{f}$ (leadership)

There is a positive relationship between leadership and policy and strategy.

As shown, policy and strategy is the dependent variable in this model, while leadership is independent variable.

Policy and strategy is the first dimension of EFQM as illustrated in the following simple regression table 3, which is the dependent variable of predictor including leadership.

$\mathrm{R}$ square is 0.449 as displayed in table 3 and the adjusted $\mathrm{R}$ square is 0.437 , which means that the leadership explain through such a model, about $44 \%$ of the variance of the policy and strategy dimension. 


\subsubsection{People $=\mathrm{f}$ (leadership)}

There is a positive relationship between leadership and people.

The second major dimension of EFQM after policy and strategy is people. The adjusted R square for the leadership is 0.068 , which means that this variable explains about $6.8 \%$ of the variance of people. Table (4) illustrates that this dimension is significant in predicting the people $(\mathrm{P}$-value $=0.006)$. Therefore, leadership has a positive impact on people and the size of its standardized coefficient.

\subsubsection{Partnership and resources $=\mathrm{f}$ (leadership)}

There is a positive relationship between leadership and partnership and resources.

Table 5 demonstrates that there is a significant relationship between leadership and partnership and resources factors. The P-value of this factor is $=0.003$. Therefore, leadership has a positive impact on partnership and resources and the size of its standardized coefficient.

6.2.4 Process $=\mathrm{f}$ (policy and strategy)

There is a positive relationship between policy and strategy and processes.

Table 6 demonstrates that there is a significant relationship between policy and strategy factors related to process, $\mathrm{P}$-value for this factor is 0.005 . Therefore, policy and strategy has a positive impact on process and the size of its standardized coefficient.

\subsubsection{Process $=\mathrm{f}($ people $)$}

There is a positive relationship between people and processes.

Table 7 shows that there is a significant relationship between people and process. People factor is a significant and $\mathrm{P}$-value for this dimension is 0.004 . Therefore, people have a positive impact on process and the size of its standardized coefficient.

\subsubsection{Process $=\mathrm{f}$ (partnership and resources)}

There is a positive relationship between partnership and resources and processes.

The adjusted $\mathrm{R}$ square for this variable is 0.019 , which means that this variable explains about $2 \%$ of the variance in process. Table 8 illustrates that this dimension is a significant in predicting the process. P-value for this dimension is 0.001 . Therefore, this dimension has a positive impact on process.

\subsubsection{People $=\mathrm{f}$ (policy and strategy)}

There is a positive relationship between policy and strategy and people.

Table 9 indicates that there is a significant relationship between policy and strategy factor and people. P-value for this dimension is 0.000 . Therefore, policy and strategy have a positive impact on people and the size of its standardized coefficient.

\subsubsection{Partnership and resources $=\mathrm{f}$ (policy and strategy)}

There is a positive relationship between policy and strategy and partnership and resources.

The adjusted $\mathrm{R}$ square for the policy and strategy is 0.039 , which means that this variable explains about $4 \%$ of the variance of partnership and resources. Table (10) illustrates that this dimension is a significant in predicting the partnership and resources $(\mathrm{P}$-value $=0.001)$. Therefore, policy and strategy has a positive impact on partnership and resources the size of its standardized coefficient.

\subsubsection{Customer results $=\mathrm{f}$ (process)}

There is a positive relationship between processes and customer results.

Table 11 demonstrates that there is a significant relationship between process and customer results factors. The P-value of this factor is $=0.003$. Therefore, process has a positive impact on customer results and the size of its standardized coefficient.

6.2.10 People results $=\mathrm{f}$ (process)

There is a positive relationship between processes and people results. 
Table 12 shows that there is a significant relationship between process and people results. People results factor is a significant and P-value for this dimension is 0.002 . Therefore, people results have a positive impact on process and the size of its standardized coefficient.

\subsubsection{Society results $=\mathrm{f}$ (process)}

There is a positive relationship between processes and society results.

The adjusted $\mathrm{R}$ square for the process is 0.015 , which means that this variable explains about $1.5 \%$ of the variance in process. Table 13 illustrates that this dimension is a significant in predicting the process. P-value for this dimension is 0.004 . Therefore, this dimension has a positive impact on society results.

\subsubsection{Key performance results $=\mathrm{f}$ (customer results)}

There is a positive relationship between customer results and key performance results.

Table 14 indicates that there is a significant relationship between customer results and key performance results. $\mathrm{P}$-value for this dimension is 0.001 . Therefore, customer results have a positive impact on key performance results and the size of its standardized coefficient.

\subsubsection{Key performance results $=\mathrm{f}$ (people results)}

There is a positive relationship between people results and key performance results.

The adjusted $\mathrm{R}$ square for the people results is 0.220 , which means that this variable explains about $22 \%$ of the variance in key performance results. Table 15 illustrates that this dimension is a significant in predicting the key performance results. P-value for this dimension is 0.000 . Therefore, this dimension has a positive impact on key performance results.

\subsubsection{Customer results $=\mathrm{f}$ (people results)}

There is a positive relationship between people results and customer results.

Table 16 indicates that there is a significant relationship between people results and customer results. P-value for this dimension is 0.000 . Therefore, people results have a positive impact on customer results and the size of its standardized coefficient.

\subsubsection{Customer results $=\mathrm{f}$ (society results)}

There is a positive relationship between society results and customer results.

Table 17 indicates that there is a significant relationship between society results and customer results. P-value for this dimension is 0.000 . Therefore, society results have a positive impact on customer results and the size of its standardized coefficient.

\subsubsection{Key performance results $=\mathrm{f}$ (society results)}

There is a positive relationship between society results and key performance results.

Table 18 indicates that there is a significant relationship between society results and key performance results. P-value for this dimension is 0.000 . Therefore, society results have a positive impact on key performance results and the size of its standardized coefficient.

\section{Research Discussion}

This section aims to discuss the findings and results that have emerged from the data analysis present in the previous section. It links the previous section and theoretical literature with the empirical side of the research.

The basic assumptions of this research are that EFQM factors namely (leadership, policy and strategy, people, partnership and resources, process, customer results, people results, society results, key performance results) influence each other's. A simple regression modeling approach was proposed as an effective method for studying the relationships. As displayed in table 3, the adjusted R2 is 0.446, suggesting that the nine EFQM factors explain close to 45 per cent of the variance for the dimension of satisfaction respectively. Of these significant variables, security, privacy, and content appear to have the greatest impact on satisfaction respectively.

This empirical evidence has provided significant support for the EFQM literature, which substantively advocates that EFQM factors have an impact on outcome.

The results empirically substantiate that EFQM factors play a fundamental among KFAFH-dental center. 


\subsection{Leadership has a positive significant influence on policy and strategy.}

The findings in table (3) provide significant support for the leadership literature which advocates that leadership have an influence upon Saudi hospitals. As a consequence, we are able to substantiate that leadership has a significant influence on policy and strategy. These findings are also consistent with other research findings (Arturo Calvo-Mora, et al, 2006; Sandra Vernero et al, 2007; Farhan et al, 2011).

\subsection{Leadership has a positive significant influence on people.}

Leadership is also considered to be one of the influential factors on the people of Saudi hospitals table (4). Prior research has empirically found positive relationship between leadership and people as critical factors on the use of EFQM (Sandra Vernero et al, 2007; Farhan et al, 2011). This is considering as logical results when Saudi health mangers believe the leadership as a strategic tool during deal with hospital staff and this might impact positively on the performance and job satisfaction of people. These findings are also consistent with other research findings. For example, (Farhan et al, 2011) found that leadership provides higher degree of excellence leading that enables people to work well in their center.

\subsection{Leadership has a positive significant influence on partnership and resources.}

Investigative data shows that a requirement for survival, development, and growth is that both the hospitals and its leaders in one side and the other side the partners and resources have an interest in their joint relationship - leading to a win-win situation in their relationship. Leadership considers as an influential factor on partnerships and resources as shown in table (5).

\subsection{Policy and strategy has a positive significant influence on processes.}

An examination of table (6) suggests that policy and strategy is a significant factor on process in dental center in KFAFH. The results therefore, substantiate that that policy and strategy has a positive bearing on process. These findings are also consistent with other research findings (Arturo Calvo-Mora, et al, 2006; Sandra Vernero et al, 2007; Farhan et al, 2011).

\subsection{People have a positive significant influence on processes.}

People are also considered to be one of the insignificant factors on the process of dental center at KFAFH table (7). Prior research has empirically found positive relationship between people and process as critical factors on adopt of EFQM (Carlos et al, 2005; Arturo Calvo-Mora, et al, 2006; Sandra Vernero et al, 2007; Farhan et al, 2011). These results indicate that the people are an important element to make possible the process of the dental center.

\subsection{Partnership and resources have a positive significant influence on processes.}

Examining data in table (8), it appears that partnership and resources has a positive significant influence on the dental center process by KFAFH. Factors such as partnership and resources may affect process. Other researchers have empirically found positive relationship between partnership and resources and process (Carlos et al, 2005; Sandra Vernero et al, 2007; Farhan et al, 2011).

\subsection{Policy and strategy have a positive significant influence on people.}

The research findings in table (9) provide support for policy and strategy having a statistically significant positive effect on people. This finding is similar to the work of Arturo Calro-Mora, et al, 2006, 2006) that identified policy and strategy as a major factor influencing people. Other researches have empirically found positive relationship between policy and strategy and people (Carlos et al, 2005; Arturo Calvo-Mora, et al, 2006; Sandra Vernero et al, 2007; Farhan et al, 2011).

\subsection{Policy and strategy have a positive significant influence on partnership and resources.}

Exploratory data in table (10), it appears that policy and strategy and resources have a positive significant influence on the partnership and resources. Factors such as policy and strategy may affect partnership and resources. Other researchers have empirically found positive relationship between policy and strategy partnership and resources (Carlos et al, 2005; Arturo Calvo-Mora, et al, 2006; Sandra Vernero et al, 2007; Farhan et al, 2011).

\subsection{Process has a positive significant influence on customer results.}

Examining data in table (11) it appears that process has a positive significant influence on the dental center customer results by KFAFH-dental center. Factors such as process may affect customer results. Other researchers have empirically found positive relationship between process and customer results. 


\subsection{Process has a positive significant influence on people results.}

Examining data in table (12) it appears that process has a positive significant influence on the dental center people results by KFAFH-dental center. Factors such as process may affect people results. Other researchers have empirically found positive relationship between process and people results (Arturo Calvo-Mora, et al, 2006; Sandra Vernero et al, 2007).

\subsection{Process has a positive significant influence on society results.}

Examining data in table (13), it appears that process has a positive significant influence on the dental center society results by KFAFH-dental center. Factors such as process may affect society results. Other researchers have empirically found positive relationship between process and society results (Carlos et al, 2005; Arturo Calvo-Mora, et al, 2006; Sandra Vernero et al, 2007; Farhan et al, 2011).

\subsection{Customer results have a positive significant influence on key performance results.}

Customer results are also considered to be one of the influential factors on the key performance results of KFAFHdental center table (14). Prior research has empirically found positive relationship between customer results and key performance results as critical factors on the use of EFQM (Carlos et al, 2005; Arturo Calvo-Mora, et al, 2006; Farhan et al, 2011). These results indicate that the customer results consider as a fruitful indicator to whole center hospitals to increase the customers/ patients satisfaction which improve the center reputation in the Saudi health marketplace. Other researchers have empirically found positive relationship between customer results as critical factors on key performance results (Carlos et al, 2005; Arturo Calvo-Mora, et al, 2006; Sandra Vernero et al, 2007; Farhan et al, 2011).

\subsection{People results have a positive significant influence on key performance results.}

People results are also considered to be one of the influential factors on the key performance results of KFAFHdental center table (15). Prior research has empirically found positive relationship between people results and key performance results as critical factors on the use of EFQM. These results indicate that the people results consider as a fruitful indicator to whole center hospitals to increase the people satisfaction which improve the center reputation in the Saudi health marketplace. Other researchers have empirically found positive relationship between people results as critical factors on key performance results (Carlos et al, 2005; Arturo Calvo-Mora, et al, 2006; Sandra Vernero et al, 2007; Farhan et al, 2011).

\subsection{People results have a positive significant influence on customer results.}

People are also considered to be one of the insignificant factors on customer results of dental center at KFAFH table (16). Prior research has empirically found positive relationship between people results and customer results as critical factors on adopt of EFQM (Farhan, et al, 2011). These results indicate that the people results is an important element to make possible the customer results of the dental center.

\subsection{Society results have a positive significant influence on customer results.}

Examining data in table (17), it appears that society results have a positive significant influence on the dental customer results by KFAFH. Factors such as society results may affect customer results. Other researchers have empirically found positive relationship between society results and customer results (Carlos et al, 2005; Arturo Calvo-Mora, et al, 2006; Sandra Vernero et al, 2007; Farhan et al, 2011).

\subsection{Society results have a positive significant influence on key performance results.}

The research findings in table (18) provide support for society results having a statistically significant positive effect on key performance results. This finding is similar to the work of Hoffman and Novak (1996) that identified society results as a major factor influencing key performance results. Other researchers have empirically found positive relationship between society results and key performance results (Arturo Calvo-Mora, et al, 2006; Sandra Vernero et al, 2007; Farhan et al, 2011).

\section{Research Conclusion and Recommendation}

\subsection{Managerial and Practical Conclusion}

The results of this research bear a number of significant empirical conclusions for researchers and practitioners in hospital management and dental centre management in particular. The research conclusions are drawn for each factor of the EFQM. 


\subsubsection{Leadership}

Leadership represent, to a great degree the most important factors influencing the policy and strategy, people, and partnership and resources. It is very necessary for managers to investigate such factors and to seek answers to how, and to what extent leaders influence dental centre in terms of their policy and strategy (e.g. consideration stakeholders needs, consideration of the political, legal, economic, and social cultural factors) people (e.g. alignment of human resources plans and policies with dental centre strategy, enabling staff to realize their full potential), and partnership and resources (e.g. identifying and managing supplier relationships).

\subsubsection{Policy and Strategy}

Policy and strategy in excellent hospitals must be based on the knowledge of key agents' expectations and needs. The interests of the different stakeholders (e.g. Saudi Ministry of Defense, Ministry of Health, SFDA, suppliers, labor market, patients, Medical Unions and associations, etc) must be balanced. Moreover, the dental centre management team should take in consideration in terms of how the policy and strategy could build a strong and long run relationship with all stakeholders deal with the dental centre. The efforts will result a win-win situation for both parties. Thus, the information gathered from stakeholders should be complemented with other additional sources of information and with performance indicators in the dental center-KFAFH.

\subsubsection{People}

The dental center that seeks excellence must be concerned with the welfare of people.

Ethical values are strictly necessary in human capital management's. Individual and professional development must be combined. That also means a labor climate based on transparency, integrity, mutual confidence and participation. The identification with the center has to be strengthened by sharing its mission, vision, values and strategy. In a convenient work environment, with an optimal work conditions, the development of people skills will increase their capacities and qualification. Equipment and tools are necessary for the development of its functions. The functions are aligned with strategy. Several measures should be undertaken to achieve the continuous improvement of social benefits. The management team at dental center-KFAFH should considering the people as an intellectual capital.

\subsubsection{Partnership}

Exceptional dental centre are linked through partnership and strategic alliances with other parties that may lead to optimize the value chain. Suppliers and other allies will be involved in the different management systems. Dental centre have to develop some of its components: one of the most influential one is human capital, and also the process towards suppliers and customers and business and social capital.

Regarding economic and financial resources, it must be said that the excellent hospital will develop procedures for controlling the expenditure defined in the annual budget and its subsequent risks. Moreover, the management of buildings, equipment and materials must follow environmental protection criteria. The consumption of resources must be rationalized.

\subsubsection{Process}

An excellent hospital will follow a process-oriented philosophy of management.

The processes must be focused on the satisfaction of internal and external customer needs and expectations. Processes, aligned with strategy, mission and objectives, have to add value to customers and other stakeholders.

This criterion makes reference to two intellectual capital components: Organizational capital (definition of key, strategic and support processes); and Relational capital (business capital).

\subsubsection{Customer Results}

Dental center should deeply link with relational capital, and more specifically, with business capital. The social capital elements "reputation", "corporative image" and "relationships with mass media" are also involved as well. According to the EFQM model, results concerning customers can be measured using indicators or assessing their perception. Different aspects must be considered: Customer perception about health services provided by the centre. In other words, customer/ patient factor is the most influential in dental centre. It is crucial for both dental centre managers and hospital managers as a whole to investigate such factors and to ensure the extent to which dental centre comprehend the needs and wants of their customers/patients when they provide them with dental health services. 


\subsubsection{People Results}

This factor fits sufficiently with human capital elements (results concerning values, attitudes, aptitudes and capacities). In this research perception and knowledge considers all the necessary activities to orchestrate an environment in which people are invited and facilitated to apply, develop, share, combine and consolidate relevant knowledge in order to achieve their individual and collective ambitions (European Foundation for Quality Management, 2005). People results are additionally a significant influential factor on dental health services. For this reason it is an important consideration given the attention by hospital managers to investigate the number of people's motivation with regard to the development of professional careers, communication, delegation, responsibility assumption, equal opportunities, involvement, leadership, learning opportunities, recognition, definition of objectives, performance evaluation, values, mission, politics and strategy, training, and promotion in the dental centre; people's satisfaction with regard to management, employment conditions, installation and services, health and safety conditions, salary, wages and benefits, relation between peers, change management, policy and environmental impact, organizational role in the community, and work environment.

\subsubsection{Society Results}

This is a key factor that should be giving a huge attention. Society is furthermore a significant influential factor on customer results and key performance results. For this reason it is an important consideration given the attention by hospital managers to have a set of socially indispensable objectives. In fact, they make an essential contribution to public welfare. As such, dental centre managers must investigate their centre because of the centre plays a well-known role in the sustainability of the dental health market, which is overall a social institution. This is the foundation of the corporate social responsibility approach. It is possible to point to some areas: (1) Active participation of the organization in social activities: ethical behavior and spread of values in society; disseminating relevant information for the community; development of a policy of equal opportunities; wealth creation and its impact on the local and national economy; and relations with relevant authorities - observation of the rules (2) Dental centre involvement with the community: involvement in social and economic development - social cohesion through collaboration with public administration and Army Forces organizations, also a universities and dentistry school as a training centre ; involvement in education and training of community members; support for cultural and social activities; and voluntary work and philanthropy.

\subsection{Limitations and Avenues for Future Research}

While this study has provided valuable insight, there are some limitations, which may limit generalisability:

1) One major difficulty with this research is that no studies have been previously performed regarding the implementation of EFQM in KSA or in Arab Region in the health sector. Although this will add to the originality and value of this study, the research will not have the added benefit of learning from others' mistakes.

2) This research has been conducted in a single service industry, the dental health service industry in KSA, exclusively in the dental centre at KFAFH, which implies that the generalisability of the research results are limited to the public hospitals in KSA within the Saudi business environment context, and cannot be generalised to other health services markets either in developed or developing countries.

In conducting this research a number of areas were identified for further research and future study. These areas include:

1) Studying the proposed model in the whole health sector among Armed Forces Hospitals in order to gain more validation for the model and more generalised findings.

2) Studying other service sectors and other health sectors e.g. public sector ( $\mathrm{MOH}$ hospitals or private sector hospitals) in order to develop a model that represents the service sector more generally, rather than representing the dental centre alone.

3) Studying the proposed model in other Gulf or Arab countries in order to gain more validation for the model and more generalised findings.

4) The same model could be used in a comparative study between the health service sector and the industrial sector in order to test the differences of EFQM in both sectors and ascertain whether the model could be more standard across a range of industries.

5) Studying all levels of dental centre employees should be involved to gather more information on this issue.

In summary, this research makes a positive contribution in the direction of EFQM in the health services. However, this research sought to overcome the limitations it encountered with the most methodological sound techniques and it 
should be followed by other efforts in the same direction. This research and similar studies will encourage other researchers to engage in more studies regarding the EFQM in the hope that such efforts will improve the relationship between the organisation, its managers and its customers with regard to greater mutual and common advantages and benefits.

\section{References}

Ahmad, A, (2012). Macro-environment Influences on Health Service Strategy in Saudi Private Sector Hospitals: An Empirical Investigation, International Business Research, 5(5), 51-64. http://dx.doi.org/10.5539/ibr.v5n5p49

Allee, V. (2000). The value evolution: addressing larger implications of an intellectual capital and intangibles perspective, Journal of Knowledge Management, 1 (1), 17-32.

Bontis, N. (2001). Assessing knowledge assets: a review of the models used to measure intellectual capital, International Journal of Management Reviews, 3 (1), 41-60. http://dx.doi.org/10.1111/1468-2370.00053

Calvo-Mora, A., Leal, A., \& Roldán, J. (2006). Using enablers of the EFQM model to manage institutions of higher education, Quality Assurance in Education, 14 (2), 99 - 122. http://dx.doi.org/10.1108/09684880610662006

Camison, C. (1996). Total quality management in hospitality. An application of the EFQM model, Tourism Management, 17 (3), 191-201. http://dx.doi.org/10.1016/0261-5177(96)00006-4

Carroll, R.F., \& Tansey, R.R. (2000). Intellectual capital in the new internet economy - its meaning, measurement and management for enhancing quality, Journal of Intellectual Capital, 1 (4), 296-312. http://dx.doi.org/10.1108/14691930010359216

Chadee, D., \& Kumar, R. (2001). Sustaining the international competitive advantage of Asian firms: a conceptual framework and research propositions, Asia Pacific Journal of Management, 18 (4), 461-80. http://dx.doi.org/10.1023/A:1012823309236

Chang, L., \& Birkett, B. (2004). Managing intellectual capital in a professional service firm: exploring the creativity-productivity paradox, Management Accounting Research, 15, 7-31. http://dx.doi.org/10.1016/j.mar.2003.10.004

De Long, W., \& Fahey, L. (2000). Diagnosing cultural barriers to knowledge management, Academy of Management Executive, 1 (4), 113-27.

Farhan, V., Zafar, F.,\& Kashif, N. (2011). Three-level quality assessment of a dental hospital using EFQM, International Journal of Health Care Quality Assurance, 24(8), 582 - 591. http://dx.doi.org/10.1108/09526861111174152

George, C., Fraser, C. \& Douglas, A. (2003). Implementing the EFQM excellence model in a local authority, Managerial Auditing Journal, 18(2), 122-127. http://dx.doi.org/10.1108/02686900310455100

Gorji, M., \& Emami, A. (2012). Self-Assessment of Organization's Performance with Regard to Enablers Criteria Excellence Model (EFQM), Research Journal of Applied Sciences, Engineering and Technology, 4(17), 3048-3055.

Grant, M. (1995). Contemporary Strategy Analysis: Concepts, Techniques, Applications, 2nd ed., Blackwell, Cambridge, MA.

Hillman, G. P. (1994). Making Self-assessment Success, Total Quality Management, 6(3), 29-31.

Jackson, S., \& Bircher, R. (2002). Transforming a run down general practice into a leading edge primary care organisation with the help of the EFQM excellence model, International Journal of Health Care Quality Assurance, 15(6), 255 - 267. http://dx.doi.org/10.1108/09526860210442029

Martin, W.J. (2004). Demonstrating knowledge value: a broader perspective on metrics, Journal of Intellectual Capital, 5 (1), 77-91. http://dx.doi.org/10.1108/14691930410512932

Martín-Castilla, J., \& Rodríguez-Ruiz, O. (2008). EFQM model: knowledge governance and competitive advantage, Journal of Intellectual Capital, 9(1), 133 - 156. http://dx.doi.org/10.1108/14691930810845858

Moeller, J., \& Sonntag, A. (2001). Evaluation of health services organisations - German experiences with the EFQM excellence approach in healthcare, The TQM Magazine, 13(5), 361 - 367. http://dx.doi.org/10.1108/EUM0000000005862

Ritchie, L., \& Dale, G. (2000). Self-assessment using the business excellence model: A study of practice and process. International Journal of Production Economics, 66 (3), 241-254. http://dx.doi.org/10.1016/S0925-5273(99)00130-9 
Rosa, J., \& Amaral, A. (2007). A self-assesment of higher education institutions from the perspective of the EFQM excellence model. In D. F. Westerheijden, B. Stensaker \& M. J. Rosa (Eds.), Quality Assurance in Higher Education: trends in regulation, translation and transformation, 20, 181-207, Springer.

Sandra,V., Udo,N.,Gilberto ., Alessio,R., \& Rita,M. (2007). A two-level EFQM self-assessment in an Italian hospital, International Journal of Health Care Quality Assurance, 20(3),215 - 231. http://dx.doi.org/10.1108/09526860710743354

Saraiva, P., Rosa, J., \& Orey, J. (2003). A large-scale Application in Portuguese Schools of the EFQM Excellence Model, Quality Progress, 36 (11), 46-51.,

Sekaran, U. (2000). Research Methods for Business. New York: John Wiley \& Sons, Inc.

Suddaby, R., \& Royston, G. (2001). Colonizing knowledge: commodification as a dynamic of jurisdictional expansion in professional, Human Relations, 54, 933-53. http://dx.doi.org/10.1177/0018726701547007

Tari, J.J. (2006). An EFQM model self-assessment exercise at a Spanish university. Journal of Educational Administration, 44(2), 170-188. http://dx.doi.org/10.1108/09578230610652051

Vallaster, C., \& Chernatony, L. (2006). Internal brand building and structuration: the role of leadership, European Journal of Marketing, 40 (7/8), 761 - 784. http://dx.doi.org/10.1108/03090560610669982

Vallejo, P., Ruiz-Sancho, A., Domínguez, M., Ayuso, MJ., Méndez, L., Romo, J., Ontoria, L., Rodriquez, P., Seriñá, C., $\&$ Arango C. (2007). Improving quality at the hospital psychiatric ward level through the use of the EFQM model, International Journal of Quality Health Care, 19 (2), 74-79. http://dx.doi.org/10.1093/intqhe/mzl074

Table 1. Research Respondents Specializations and Levels

\begin{tabular}{|l|c|}
\hline \multicolumn{1}{|c|}{ Specialization } & Numbers \\
\hline Management (Dentist) & 5 \\
\hline Management (Administrative) & 3 \\
\hline Faculties & 10 \\
\hline Students & 32 \\
\hline Total & 50 \\
\hline
\end{tabular}


Table 2. EFQM

\begin{tabular}{|c|c|c|c|c|c|c|c|c|c|c|c|}
\hline & & 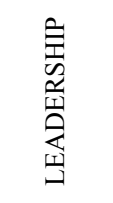 & 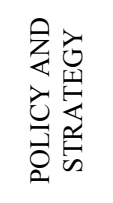 & 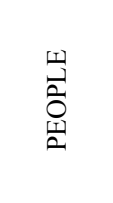 & 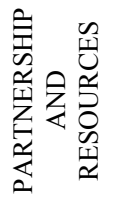 & 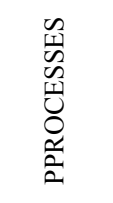 & 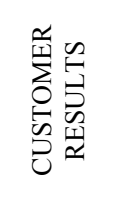 & 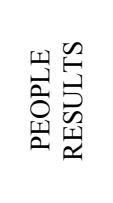 & 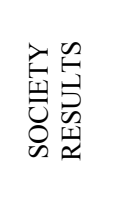 & 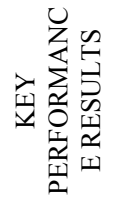 & $\frac{\mathscr{E}}{\stackrel{\Xi}{\Xi}}$ \\
\hline \multirow[t]{3}{*}{ LEADERSHIP } & $\begin{array}{l}\text { Pearson } \\
\text { Correlation }\end{array}$ & 1 & & & & & & & & & \\
\hline & $\begin{array}{l}\text { Sig. } \\
\text { (2-tailed) }\end{array}$ & . & & & & & & & & & \\
\hline & $\mathrm{N}$ & 50 & & & & & & & & & \\
\hline \multirow[t]{3}{*}{$\begin{array}{l}\text { POLICY AND } \\
\text { STRATEGY }\end{array}$} & $\begin{array}{l}\text { Pearson } \\
\text { Correlation }\end{array}$ & $.670(* *)$ & 1 & & & & & & & & \\
\hline & $\begin{array}{l}\text { Sig. } \\
(2 \text {-tailed) }\end{array}$ & .000 & . & & & & & & & & \\
\hline & $\mathrm{N}$ & 50 & 50 & & & & & & & & \\
\hline \multirow[t]{3}{*}{ PEOPLE } & $\begin{array}{l}\text { Pearson } \\
\text { Correlation }\end{array}$ & $.295(*)$ & $.683(* *)$ & 1 & & & & & & & \\
\hline & $\begin{array}{l}\text { Sig. } \\
\text { (2-tailed) }\end{array}$ & .037 & .000 & . & & & & & & & \\
\hline & $\mathrm{N}$ & 50 & 50 & 50 & & & & & & & \\
\hline \multirow[t]{3}{*}{$\begin{array}{l}\text { PARTNERSHIP } \\
\text { AND RESOURCES }\end{array}$} & $\begin{array}{l}\text { Pearson } \\
\text { Correlation }\end{array}$ & $.603(* *)$ & $.783(* *)$ & $.524(* *)$ & 1 & & & & & & \\
\hline & $\begin{array}{l}\text { Sig. } \\
\text { (2-tailed) }\end{array}$ & .000 & .000 & .000 & . & & & & & & \\
\hline & $\mathrm{N}$ & 50 & 50 & 50 & 50 & & & & & & \\
\hline \multirow[t]{3}{*}{ PPROCESSES } & $\begin{array}{l}\text { Pearson } \\
\text { Correlation }\end{array}$ & $.308(*)$ & $.356(*)$ & $.297(*)$ & $.613(* *)$ & 1 & & & & & \\
\hline & $\begin{array}{l}\text { Sig. } \\
\text { (2-tailed) }\end{array}$ & .041 & .011 & .043 & .000 & . & & & & & \\
\hline & $\mathrm{N}$ & 50 & 50 & 50 & 50 & 50 & & & & & \\
\hline \multirow[t]{3}{*}{$\begin{array}{l}\text { CUSTOMER } \\
\text { RESULTS }\end{array}$} & $\begin{array}{l}\text { Pearson } \\
\text { Correlation }\end{array}$ & $.451(* *)$ & $.490(* *)$ & $.787(*)$ & $.778(* *)$ & $.545(* *)$ & 1 & & & & \\
\hline & $\begin{array}{l}\text { Sig. } \\
\text { (2-tailed) }\end{array}$ & .001 & .000 & .033 & .001 & .000 & . & & & & \\
\hline & $\mathrm{N}$ & 50 & 50 & 50 & 50 & 50 & 50 & & & & \\
\hline \multirow[t]{3}{*}{ PEOPLE RESULTS } & $\begin{array}{l}\text { Pearson } \\
\text { Correlation } \\
\end{array}$ & $.354(*)$ & $.287(*)$ & $.287(*)$ & $.348(* *)$ & $.348(*)$ & $.888(* *)$ & 1 & & & \\
\hline & $\begin{array}{l}\text { Sig. } \\
\text { (2-tailed) }\end{array}$ & .012 & .043 & .043 & .009 & .020 & .000 & . & & & \\
\hline & $\mathrm{N}$ & 50 & 50 & 50 & 50 & 50 & 50 & 50 & & & \\
\hline \multirow[t]{3}{*}{ SOCIETY RESULTS } & $\begin{array}{l}\text { Pearson } \\
\text { Correlation }\end{array}$ & $.349(*)$ & $.328(*)$ & $.287(*)$ & $.277(*)$ & $.396\left(^{*}\right)$ & $.806(* *)$ & $.819(* *)$ & 1 & & \\
\hline & $\begin{array}{l}\text { Sig. } \\
(2 \text {-tailed) }\end{array}$ & .013 & .020 & .043 & .043 & .021 & .000 & .000 & . & & \\
\hline & $\mathrm{N}$ & 50 & 50 & 50 & 50 & 50 & 50 & 50 & 50 & & \\
\hline \multirow{3}{*}{$\begin{array}{l}\text { KEY } \\
\text { PERFORMANCE } \\
\text { RESULTS }\end{array}$} & $\begin{array}{l}\text { Pearson } \\
\text { Correlation }\end{array}$ & $.410(* *)$ & $.317\left(^{*}\right)$ & $.558(* *)$ & $.306(*)$ & $.297(*)$ & $.438(* *)$ & $.486\left(^{* *}\right)$ & $.668(* *)$ & 1 & \\
\hline & $\begin{array}{l}\text { Sig. } \\
(2 \text {-tailed) }\end{array}$ & .003 & .025 & .000 & .031 & .043 & .001 & .000 & .000 & . & \\
\hline & $\mathrm{N}$ & 50 & 50 & 50 & 50 & 50 & 50 & 50 & 50 & 50 & \\
\hline \multirow[t]{3}{*}{ All items } & $\begin{array}{l}\text { Pearson } \\
\text { Correlation }\end{array}$ & $.444(* *)$ & $.675(* *)$ & $.756(* *)$ & $.446(* *)$ & $.381(* *)$ & $.612(* *)$ & $.607(* *)$ & $.736(* *)$ & $.725(* *)$ & 1 \\
\hline & $\begin{array}{l}\text { Sig. } \\
\text { (2-tailed) }\end{array}$ & .001 & .000 & .000 & .001 & .006 & .000 & .000 & .000 & .000 & . \\
\hline & $\mathrm{N}$ & 50 & 50 & 50 & 50 & 50 & 50 & 50 & 50 & 50 & 50 \\
\hline
\end{tabular}

** Correlation is significant at the 0.01 level (2-tailed).

* Correlation is significant at the 0.05 level (2-tailed). 
Table 3. Coefficient of the multiple regression model/ policy and strategy

\begin{tabular}{|c|c|c|c|c|c|c|}
\hline \multirow[t]{2}{*}{ Model } & & \multicolumn{2}{|c|}{ Unstandardized Coefficients } & $\begin{array}{l}\text { Standardized } \\
\text { Coefficients }\end{array}$ & \multirow[t]{2}{*}{$\mathrm{T}$} & \multirow[t]{2}{*}{ Sig. } \\
\hline & & B & Std. Error & Beta & & \\
\hline \multirow[t]{2}{*}{1} & (Constant) & 618 & .679 & & .911 & .000 \\
\hline & Leadership & .858 & .137 & .670 & 6.250 & .000 \\
\hline \multicolumn{3}{|c|}{ a Dependent Variable: policy and strategy } & $\mathrm{R}^{2}=0.449$ & $\begin{array}{l}\text { adjusted } R^{2} \\
\quad=0.437\end{array}$ & $\mathrm{~F}=39.60$ & $\mathrm{P}<0.05$ \\
\hline
\end{tabular}

Table 4. Coefficient of the Multiple Regression Model/People

\begin{tabular}{|c|c|c|c|c|c|c|}
\hline \multirow[t]{2}{*}{ Model } & & \multicolumn{2}{|c|}{ Unstandardized Coefficients } & \multirow{2}{*}{$\begin{array}{c}\text { Standardized } \\
\text { Coefficients } \\
\text { Beta }\end{array}$} & \multirow[t]{2}{*}{$\mathrm{T}$} & \multirow[t]{2}{*}{ Sig. } \\
\hline & & $\mathrm{B}$ & Std. Error & & & \\
\hline \multirow[t]{2}{*}{1} & (Constant) & 2.740 & .960 & & 2.853 & .006 \\
\hline & $\begin{array}{l}\text { LEADERS } \\
\text { HIP }\end{array}$ & .416 & .194 & .295 & 2.141 & .037 \\
\hline \multicolumn{3}{|c|}{ a Dependent Variable: People } & $\mathrm{R}^{2}=0.087$ & $\begin{array}{c}\text { adjusted } \mathrm{R}^{2} \\
=0.068\end{array}$ & $\begin{array}{c}\mathrm{F}=4.58 \\
4\end{array}$ & $\mathrm{P}<0.05$ \\
\hline
\end{tabular}

Table 5. Coefficient of the Multiple Regression Model/ Partnership and resources

\begin{tabular}{|l|l|r|r|r|r|r|}
\hline \multirow{2}{*}{ Model } & & \multicolumn{2}{|c|}{ Unstandardized Coefficients } & $\begin{array}{c}\text { Standardized } \\
\text { Coefficients }\end{array}$ & $\mathrm{T}$ & Sig. \\
\hline & & $\mathrm{B}$ & Std. Error & Beta & & \\
\hline 1 & & .822 & & 9.280 & .000 \\
\hline & $\begin{array}{l}\text { LEADERS } \\
\text { HIP }\end{array}$ & .530 & .166 & .418 & 3.187 & .003 \\
\hline \multicolumn{2}{|c|}{$\begin{array}{l}\text { Dependent Variable: partnership and } \\
\text { resources }\end{array}$} & $\mathrm{R}^{2}=0.175$ & $\begin{array}{c}\text { adjusted } \mathrm{R}^{2} \\
=0.157\end{array}$ & $\mathrm{~F}=10.156$ & $\mathrm{P}<0.05$ \\
\hline
\end{tabular}

Table 6. Coefficient of the Multiple Regression Model/Process

\begin{tabular}{|c|c|c|c|c|c|c|}
\hline \multirow[t]{2}{*}{ Model } & & \multicolumn{2}{|c|}{$\begin{array}{c}\text { Unstandardized } \\
\text { Coefficients }\end{array}$} & $\begin{array}{l}\text { Standardi } \\
\text { zed } \\
\text { Coefficie } \\
\text { nts }\end{array}$ & \multirow[t]{2}{*}{$\mathrm{T}$} & \multirow[t]{2}{*}{ Sig. } \\
\hline & & $\mathrm{B}$ & Std. Error & Beta & & \\
\hline \multirow[t]{2}{*}{1} & (Constant) & 6.196 & 1.029 & & 6.022 & .000 \\
\hline & $\begin{array}{l}\text { POLICY AND } \\
\text { STRATEGY }\end{array}$ & .162 & .211 & .110 & .769 & .005 \\
\hline \multicolumn{2}{|c|}{ Dependent Variable: Process } & \multicolumn{2}{|c|}{$\mathrm{R}^{2}=0.012$} & $\begin{array}{c}\text { adjusted } \\
\mathrm{R}^{2}= \\
-0.008\end{array}$ & $\mathrm{~F}=0.592$ & $\mathrm{P}<0.05$ \\
\hline
\end{tabular}


Table 7. Coefficient of the Multiple Regression Model/process

\begin{tabular}{|c|c|c|c|c|c|c|}
\hline \multirow[t]{2}{*}{ Model } & & \multicolumn{2}{|c|}{$\begin{array}{c}\text { Unstandardized } \\
\text { Coefficients }\end{array}$} & \multirow{2}{*}{$\begin{array}{c}\text { Standardized } \\
\text { Coefficients } \\
\text { Beta }\end{array}$} & \multirow[t]{2}{*}{$\mathrm{T}$} & \multirow[t]{2}{*}{ Sig. } \\
\hline & & $\mathrm{B}$ & Std. Error & & & \\
\hline \multirow[t]{2}{*}{1} & (Constant & 3.974 & .908 & & 4.379 & .000 \\
\hline & PEOPLE & .299 & .188 & .224 & 1.589 & .004 \\
\hline \multicolumn{3}{|c|}{ Dependent Variable: process } & $\mathrm{R}^{2}=0.050$ & $\begin{array}{l}\text { adjusted } \mathrm{R}^{2} \\
=0.030\end{array}$ & $\mathrm{~F}=2.524$ & $\mathrm{P}<0.05$ \\
\hline
\end{tabular}

Table 8. Coefficient of the Multiple Regression Model/Process

\begin{tabular}{|c|c|c|c|c|c|c|}
\hline \multirow[t]{2}{*}{ Model } & & \multicolumn{2}{|c|}{$\begin{array}{l}\text { Unstandardized } \\
\text { Coefficients }\end{array}$} & \multirow{2}{*}{$\begin{array}{c}\text { Standardized } \\
\text { Coefficients } \\
\text { Beta }\end{array}$} & \multirow[t]{2}{*}{$\mathrm{T}$} & \multirow[t]{2}{*}{ Sig. } \\
\hline & & $\mathrm{B}$ & Std. Error & & & \\
\hline \multirow[t]{2}{*}{1} & (Constant) & 4.375 & 1.071 & & 4.085 & .000 \\
\hline & $\begin{array}{l}\text { PARTNERSH } \\
\text { IP AND } \\
\text { RESOURCES }\end{array}$ & .206 & .213 & .138 & .969 & .001 \\
\hline \multicolumn{3}{|c|}{ Dependent Variable: Process } & $\mathrm{R}^{2}=0.019$ & $\begin{array}{l}\text { adjusted } \mathrm{R}^{2} \\
=-0.001\end{array}$ & $\mathrm{~F}=0.938$ & $\mathrm{P}<0.05$ \\
\hline
\end{tabular}

Table 9. Coefficient of the Multiple Regression Model/People

\begin{tabular}{|c|c|c|c|c|c|c|}
\hline \multirow[t]{2}{*}{ Model } & & \multicolumn{2}{|c|}{$\begin{array}{l}\text { Unstandardized } \\
\text { Coefficients }\end{array}$} & \multirow{2}{*}{$\begin{array}{c}\text { Standardized } \\
\text { Coefficients } \\
\text { Beta }\end{array}$} & \multirow[t]{2}{*}{$\mathrm{t}$} & \multirow[t]{2}{*}{ Sig. } \\
\hline & & B & Std. Error & & & \\
\hline \multirow[t]{2}{*}{1} & (Constant) & 1.147 & .564 & & $\begin{array}{r}2.03 \\
2\end{array}$ & .000 \\
\hline & $\begin{array}{l}\text { POLICY AND } \\
\text { STRATEGY }\end{array}$ & .751 & .116 & .683 & $\begin{array}{r}6.48 \\
4\end{array}$ & .000 \\
\hline \multicolumn{3}{|c|}{ Dependent Variable: People } & $\mathrm{R}^{2}=0.467$ & $\begin{array}{l}\text { adjusted } \mathrm{R}^{2} \\
=0.456\end{array}$ & $\begin{array}{l}\mathrm{F}=4 \\
2.43\end{array}$ & $\mathrm{P}<0.05$ \\
\hline
\end{tabular}

Table 10. Coefficient of the Multiple Regression Model/Partnership and resources

\begin{tabular}{|c|c|c|c|c|c|c|}
\hline \multirow[t]{2}{*}{ Model } & & \multicolumn{2}{|c|}{$\begin{array}{l}\text { Unstandardized } \\
\text { Coefficients }\end{array}$} & \multirow{2}{*}{$\begin{array}{c}\text { Standardized } \\
\text { Coefficients } \\
\text { Beta }\end{array}$} & \multirow[t]{2}{*}{$\mathrm{t}$} & \multirow[t]{2}{*}{ Sig. } \\
\hline & & B & Std. Error & & & \\
\hline \multirow[t]{2}{*}{1} & (Constant) & 4.434 & .691 & & 6.418 & .000 \\
\hline & $\begin{array}{l}\text { POLICY AND } \\
\text { STRATEGY }\end{array}$ & .120 & .142 & .121 & .848 & .001 \\
\hline \multicolumn{2}{|c|}{$\begin{array}{c}\text { a Dependent Variable: Partnership } \\
\text { and resources }\end{array}$} & \multicolumn{2}{|c|}{$\mathrm{R}^{2}=0.015$} & $\begin{array}{l}\text { adjusted } \mathrm{R}^{2} \\
=-0.039\end{array}$ & $\mathrm{~F}=0.719$ & $\mathrm{P}<0.05$ \\
\hline
\end{tabular}


Table 11. Coefficient of the Multiple Regression Model/ customer results

\begin{tabular}{|c|c|c|c|c|c|c|}
\hline \multirow[t]{2}{*}{ Model } & & \multicolumn{2}{|c|}{$\begin{array}{c}\text { Unstandardized } \\
\text { Coefficients }\end{array}$} & \multirow{2}{*}{$\begin{array}{c}\begin{array}{c}\text { Standardized } \\
\text { Coefficients }\end{array} \\
\text { Beta } \\
\end{array}$} & \multirow[t]{2}{*}{$\mathrm{t}$} & \multirow[t]{2}{*}{ Sig. } \\
\hline & & B & Std. Error & & & \\
\hline \multirow[t]{2}{*}{1} & (Constant) & 7.631 & .822 & & 9.280 & .000 \\
\hline & PROCESS & .530 & .166 & .418 & 3.187 & .003 \\
\hline Depen & Variable: cu & results & $\mathrm{R}^{2}=0.175$ & $\begin{array}{l}\text { adjusted } \mathrm{R}^{2} \\
\quad=0.157\end{array}$ & $\mathrm{~F}=10.156$ & $\mathrm{P}<0.05$ \\
\hline
\end{tabular}

Table 12. Coefficient of the Multiple Regression Model/people results

\begin{tabular}{|c|c|c|c|c|c|c|}
\hline \multirow[t]{2}{*}{ Model } & & \multicolumn{2}{|c|}{$\begin{array}{c}\text { Unstandardized } \\
\text { Coefficients }\end{array}$} & \multirow{2}{*}{$\begin{array}{c}\text { Standardized } \\
\text { Coefficients } \\
\text { Beta }\end{array}$} & \multirow[t]{2}{*}{$\mathrm{t}$} & \multirow[t]{2}{*}{ Sig. } \\
\hline & & $\mathrm{B}$ & Std. Error & & & \\
\hline \multirow[t]{2}{*}{1} & (Constant) & 4.987 & .488 & & 10.222 & .000 \\
\hline & $\begin{array}{l}\text { PPROCESS } \\
\text { ES }\end{array}$ & .039 & .090 & .063 & .440 & .002 \\
\hline \multicolumn{3}{|c|}{ Dependent Variable: people results } & $\mathrm{R}^{2}=0.004$ & $\begin{array}{c}\text { adjusted } \mathrm{R}^{2} \\
=-0.017\end{array}$ & $\mathrm{~F}=1.94$ & $\mathrm{P}<0.05$ \\
\hline
\end{tabular}

Table 13. Coefficient of the Multiple Regression Model/society results

\begin{tabular}{|c|c|c|c|c|c|c|}
\hline \multirow[t]{2}{*}{ Model } & & \multicolumn{2}{|c|}{$\begin{array}{c}\text { Unstandardized Co } \\
\text { efficients }\end{array}$} & \multirow{2}{*}{$\begin{array}{c}\text { Standardized } \\
\text { Coefficients } \\
\text { Beta }\end{array}$} & \multirow[t]{2}{*}{$\mathrm{T}$} & \multirow[t]{2}{*}{ Sig. } \\
\hline & & B & Std. Error & & & \\
\hline \multirow[t]{2}{*}{1} & (Constant) & 5.068 & .440 & & 11.525 & .000 \\
\hline & $\begin{array}{l}\text { PPROCESS } \\
\text { ES }\end{array}$ & .042 & .081 & .075 & .522 & .004 \\
\hline Dep & Variable: so & results & $\mathrm{R}^{2}=0.006$ & $\begin{array}{l}\text { adjusted } \mathrm{R}^{2} \\
=-0.015\end{array}$ & $\mathrm{~F}=0.272$ & $\mathrm{P}<0.05$ \\
\hline
\end{tabular}

Table 14. Coefficient of the Multiple Regression Model/ key performance results

\begin{tabular}{|c|c|c|c|c|c|c|}
\hline \multirow[t]{2}{*}{ Model } & & \multicolumn{2}{|c|}{$\begin{array}{c}\text { Unstandardized } \\
\text { Coefficients }\end{array}$} & \multirow{2}{*}{$\begin{array}{c}\text { Standardized } \\
\text { Coefficients } \\
\text { Beta }\end{array}$} & \multirow[t]{2}{*}{$\mathrm{t}$} & \multirow[t]{2}{*}{ Sig. } \\
\hline & & $\mathrm{B}$ & Std. Error & & & \\
\hline \multirow[t]{2}{*}{1} & (Constant) & 3.680 & .440 & & 8.359 & .000 \\
\hline & $\begin{array}{l}\text { CUSTOMER } \\
\text { RESULTS }\end{array}$ & .284 & .084 & .438 & 3.378 & .001 \\
\hline \multicolumn{2}{|c|}{$\begin{array}{l}\text { Dependent Variable: key } \\
\text { performance results }\end{array}$} & \multicolumn{2}{|c|}{$\mathrm{R}^{2}=0.192$} & $\begin{array}{l}\text { adjusted } \mathrm{R}^{2} \\
\quad=0.175\end{array}$ & $\mathrm{~F}=11.412$ & $\mathrm{P}<0.05$ \\
\hline
\end{tabular}

Table 15. Coefficient of the Multiple Regression Model/ key performance results

\begin{tabular}{|l|l|r|r|r|r|r|}
\hline \multirow{2}{*}{ Model } & & \multicolumn{2}{|c|}{$\begin{array}{c}\text { Unstandardized } \\
\text { Coefficients }\end{array}$} & $\begin{array}{c}\text { Standardized } \\
\text { Coefficients }\end{array}$ & \multicolumn{1}{c|}{ S } & Sig. \\
\hline & & \multicolumn{1}{c|}{ B } & Std. Error & Beta & & \\
\hline 1 & (Constant) & 3.203 & .510 & & 6.276 & .000 \\
\hline & $\begin{array}{l}\text { PEOPLE } \\
\text { RESULTS }\end{array}$ & .376 & .098 & .486 & 3.848 & .000 \\
\hline
\end{tabular}

\begin{tabular}{|l|l|c|c|c|}
\hline Dependent Variable: key performance results & $\mathrm{R}^{2}=0.236$ & $\begin{array}{c}\text { adjusted } \mathrm{R}^{2} \\
=0.220\end{array}$ & $\mathrm{~F}=14.810$ & $\mathrm{P}<0.05$ \\
\hline
\end{tabular}


Table 16. Coefficient of the Multiple Regression Model/ customer results

\begin{tabular}{|l|l|r|r|r|r|r|}
\hline Model & & \multicolumn{2}{|c|}{$\begin{array}{c}\text { Unstandardized } \\
\text { Coefficients }\end{array}$} & $\begin{array}{c}\text { Standardized } \\
\text { Coefficients }\end{array}$ & \multicolumn{1}{c|}{$\mathrm{T}$} & Sig. \\
\hline 1 & \multicolumn{1}{c|}{ B } & Std. Error & \multicolumn{1}{c|}{ Beta } & & .000 \\
\hline & (Constant) & .310 & .415 & & .747 & .000 \\
\hline & $\begin{array}{l}\text { PEOPLE } \\
\text { RESULTS }\end{array}$ & 1.063 & .080 & .888 & 13.356 & $\mathrm{P}<0.05$ \\
\hline
\end{tabular}

Table 17. Coefficient of the Multiple Regression Model/ customer results

\begin{tabular}{|c|c|c|c|c|c|c|}
\hline \multirow[t]{2}{*}{ Model } & & \multicolumn{2}{|c|}{$\begin{array}{c}\text { Unstandardized } \\
\text { Coefficients }\end{array}$} & \multirow{2}{*}{$\begin{array}{c}\text { Standardized } \\
\text { Coefficients } \\
\text { Beta }\end{array}$} & \multirow[t]{2}{*}{$\mathrm{T}$} & \multirow[t]{2}{*}{ Sig. } \\
\hline & & B & Std. Error & & & \\
\hline \multirow[t]{2}{*}{1} & (Constant) & .448 & .602 & & .744 & .000 \\
\hline & $\begin{array}{l}\text { SOCIETY } \\
\text { RESULTS }\end{array}$ & 1.070 & .113 & .806 & 9.434 & .000 \\
\hline Dep & riable: cus & & $\mathrm{R}^{2}=0.650$ & $\begin{array}{l}\text { adjusted } \mathrm{R}^{2} \\
\quad=0.642\end{array}$ & $\mathrm{~F}=88.997$ & $\mathrm{P}<0.05$ \\
\hline
\end{tabular}

Table 18. Coefficient of the Multiple Regression Model/ key performance results

\begin{tabular}{|c|c|c|c|c|c|c|c|c|}
\hline \multirow[b]{2}{*}{ Model } & & \multicolumn{3}{|c|}{$\begin{array}{l}\text { Unstandardized } \\
\text { Coefficients }\end{array}$} & \multicolumn{2}{|c|}{$\begin{array}{l}\text { Standardized } \\
\text { Coefficients }\end{array}$} & \multirow[b]{2}{*}{$\mathrm{T}$} & \multirow[b]{2}{*}{ Sig. } \\
\hline & & B & & Std. Error & Beta & & & \\
\hline \multirow[t]{2}{*}{1} & (Constant) & & & .490 & & & 4.326 & .000 \\
\hline & $\begin{array}{l}\text { SOCIETY } \\
\text { RESULTS }\end{array}$ & & & .092 & & & 6.223 & .000 \\
\hline \multicolumn{3}{|c|}{$\begin{array}{c}\text { Dependent Variable: key performance } \\
\text { results }\end{array}$} & & $=0.447$ & $\begin{array}{l}\text { adjusted } \mathrm{R}^{2} \\
=0.435\end{array}$ & & 728 & $\mathrm{P}<0.05$ \\
\hline
\end{tabular}

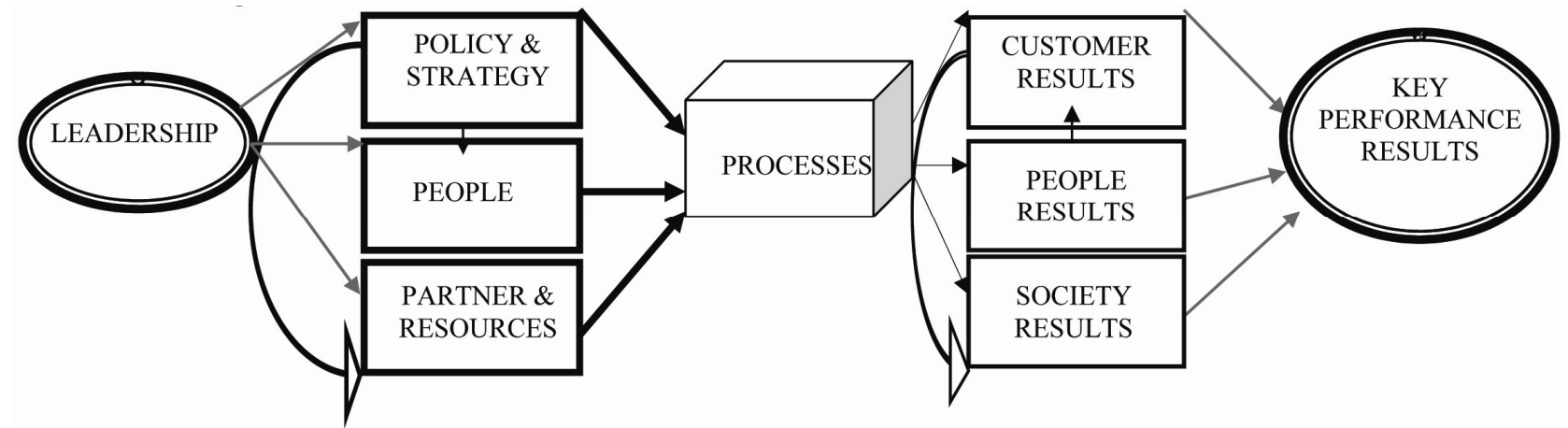

Figure 1. Research Model 